\title{
Effect of Goji Berries (Lycium Barbarum) Extract and Some Nanoparticles Loaded on Gelatin Film in Chemical Properties of Labneh
}

\author{
${ }^{1}$ Oroba Bahjat Shihab, ${ }^{1}$ Mohammed Ahmed Jassim, ${ }^{2}$ Hashim Mohammed Zehraw* \\ ${ }^{1}$ Department of Food Science, College of Agriculture, Tikrit University - Iraq \\ ${ }^{2}$ Abn Albetar Center/ Corporation of Research and Industrial Development - Iraq
}

\section{Article information}

\section{Article history:}

Received: August, 10, 2021

Accepted: October, 04, 2021

Available online: October, 20, 2021

Keywords:

Lycium Barbarum,

Labneh,

Nanoparticles

\section{*Corresponding Author:}

Hashim Mohammed Zehraw

hzehraw@gmail.com

DOI:

https://doi.org/10.53523/ijoirVol8I2ID63

\begin{abstract}
This study is conducted to evaluate the effect of Lycium barbarum extract (Goji berries), Chitosan nanoparticle (ChNPs), titanium dioxide nanoparticle $\left(\mathrm{TiO}_{2} \mathrm{NPs}\right)$ loaded on Gelatin films in terms of the chemical composition of labneh during different storage periods. The samples were divided into seven treatment procedures, include (T1) non-coated labneh, (T2) labneh coated with Gelatin membranes, (T3) labneh coated with Gelatin membranes and Lycium barbarum extract, (T4) labneh coated with Gelatin films and ChNPs, (T5) labneh coated with Gelatin films treated $\mathrm{TiO}_{2} \mathrm{NPs}$, (T6) Labneh coated with Gelatin films, Lycium barbarum, ChNPs, (T7) Labneh coated with Gelatin films, Lycium barbarum, $\mathrm{TiO}_{2} \mathrm{NPs}$. The results showed that the moisture percentage decreased significantly $(\mathrm{p}<0.05)$ untilthe end of the storage period, and treatment T6 was less in the rate of moisture loss $(72.35 \%)$. It was also found that the ratios of protein, fat, ash, did not show significant differences at the time of one day compared with the two control samples $\mathrm{T} 1$ and $\mathrm{T} 2$, These percentages increased gradually as the duration of preservation was prolonged and reached their highest values at the time of 14 days. The $\mathrm{pH}$ values decreased significantly between (4.36-4.32) at the end of the storage period, compared with the two control samples $\mathrm{T} 1$ and $\mathrm{T} 2$, which were at 4.16 and 4.23 , respectively. It was found that the fatty acid values of all treatments were significantly low compared with the control treatment $\mathrm{T} 1$ at the time of one dayThe free fatty acid ratios increased and reached their highest values between $(0.29-0.32)$ for all treatments compared with the two control treatments $\mathrm{T} 1$ and $\mathrm{T} 2$ at the end of the storage period which amounted to $(0.39$ and 0.35$) \%$.
\end{abstract}

\section{Introduction}

Labneh is a dairy product that is characterized by its high content of nutrients in yogurt. It can be of Low-fat content or completely defatted. One tablespoon of skimmed labneh contains only ten calories." Sales of labneh increased due to its nutritional importance in the United States of America during the first nine months of 2006 
by about $70 \%$ compared to 2005 [1]." One of the methods used to extend the shelf life of perishable foods is extracts and nanoparticles. Lycium barbarum is a tree that grows in dry and hot areas and belongs to the Solanaceae family and spreads all over the world due to its various uses and is of thehigh nutritional value as it contains 100 grams of the dry fruits have the proportions of the following components $(68 \%)$ carbohydrates, $(12 \%)$ protein, (10\%) fats and are rich in vitamins [2]." Chitosan is obtained from chitin after treating it with the base Chitosan possesses three unctional groups that enable these groups of chitosan to perform many different functions in the medical, pharmaceutical fields, the fields of food, agricultural and industrial manufacturing [3]." Titanium dioxide (TiO2NPs) is obtained naturally from many types of mineral rocks. It is a solid inorganic substance, white in color, thermally stable, poorly soluble, and not classified as hazardous under the United Nations Chemicals Classification and Teaching System. It is non-toxic, so it is used in human food, medicines, Food contact materials [4]."

\section{Experimental Procedure}

Goji Berries extract (GBE): The extraction was carried out according to the method mentioned by Chan et al. [5], in preparing the alcoholic extract of G.B., as (20) g of G.B. powder was taken with (200) ml of ethyl alcohol at a concentration of $(100 \%)$ in a conical flask, then transferred to A vibrating water bath at a speed of 250 cycle/ minute at a temperature of $60^{\circ} \mathrm{C}$ for 240 minutes. After that, the extract was filtered using filter paper (Whatman No: 1), Evaporation was carried out using a rotary evaporator to obtain the concentrated extract, then it was dried using the oven at a temperature of $50^{\circ} \mathrm{C}$ for 24 hours. In the form of a dried powder, a solution of concentration (10) $\mathrm{mg} / \mathrm{ml}$ is obtained.Nanoparticles: Chitosan nanoparticles equipped from the Chinese company (Trading) were used with the following specifications: purity: $96.27 \%$, viscosity: 25 centipoises, percentage of ash: $0.73 \%$, percentage moisture: $9.45 \%$, particle size: $26 \mathrm{~nm}$ and density: $0.32 \mathrm{~g} / \mathrm{cm} 2$. White powder. While the titanium dioxide particles equipped by the American company (NANOSHEL), had the following specifications, purity: $99.1 \%$, the special surface area was greater than $30 \mathrm{~m} 2 / \mathrm{g}$, the particle size was less than 25-48 nanometers, and the density was $0.3 \mathrm{~g} / \mathrm{cm} 2$, which had a laminate appearance in the form of an odorless white powder.

Gelatin Film Preparation: Membrane solutions were prepared according to the De Carvalho and Grosso method, [6] with a weight of $10 \mathrm{~g}$ of gelatin powder, dissolved in $80 \mathrm{ml}$ distilled water, and mixed all the ingredients using a hot plate magnetic stirrer at $60^{\circ} \mathrm{C}$ for 15 minutes and then added $30 \%$ glycerol. Weigh the dry gelatin and complete the volume to $100 \mathrm{ml}$ of distilled water, adjusting the $\mathrm{pH}=7$. Add the extract and the nanoparticles inside the membrane solution to a vacuum pump for 10 minutes to get rid of air bubbles and keep the mixture in the refrigerator in dark conditions to prevent the occurrence of operations Oxidative stress.

Pouring and drying the film-forming solutions: The casting and drying process of the film solutions took place in plastic dishes with an inner diameter of $18 \mathrm{~cm}$, and the volume was chosen $30 \mathrm{ml}$ after carrying out several initial experiments to obtain the appropriate thickness of the membrane, then spread the solution quietly by moving the plate left and right on a flat and stable surface to ensure uniform distribution over the area of the plate, then the dishes were dried at room temperature $25-30^{\circ} \mathrm{C}$ for $20-24$ hours, after which the films were removed from the dishes and placed in polyethylene bags and kept in the refrigerator [7].

How to make labneh: Labneh was manufactured in the laboratory using whol fat cow's milk, where it was thermally treated at $90^{\circ} \mathrm{C}$ for five minutes in a water bath and then cooled to a temperature of $45^{\circ} \mathrm{C}$ and inoculated with the prepared milk starter in the form of dry cells (Lactobacillus bulgaricus and Streptococcus thermophiles) the rate of $3 \%$ and incubated at $42{ }^{\circ} \mathrm{C}$ for 3-4 hours, after complete coagulation, the curd was left to cool at room temperature for an hour, after which it was placed in the fridge at a temperature of $5{ }^{\circ} \mathrm{C}$ for 24 hours, after that, it was placed in a clean cloth bag adding it $0.5 \%$ salt and placed it in the refrigerator at $5^{\circ} \mathrm{C}$ for 22 hours. After that, empty the filter bag into a clean plastic container and store it at $6^{\circ} \mathrm{C}$ in the refrigerator [8].

Packaging of Labneh Samples: Labneh samples were cut in a rectangular shape and weighing 50 gm for the sample to ensure that the envelopes are wholy contained in the models and encapsulated with gelatin films, then stored in the fridge until the tests are carried out and according to the suggested periods.Chemical examinations for labneh: humidity was estimated according to the Ling method [9], and the Kerber method mentioned by Min and Ellefson [10] was followed to estimate the percentage of fat, the protein and $\mathrm{pH}$ were calculated as 
mentioned by Hool et al. [11], ash and free fatty acids were estimated by the direct burning method described in AOAC [12], the carbohydrate fraction was mathematically studied according to Thekoronye [13].

Statistical analysis: The results of the experiments were analyzed using the Linear Model General within the ready-made statistical program SAS [14] to study the effect of factors on the complete random design of the CRD. Duncan test [15]was performed to determine the significance of the differences between the factors affecting the traits studied at (0.05) level.Results and Discussion

\section{Results and Discussion}

Moisture percentage: The results in Table (1) showed that after one day of storage, no significant difference was found in the moisture percentage in all treatments The humidity ranged on the first day between (77.30) to 78.15). All samples showed a significant decrease $(\mathrm{P}<0.05)$ in the moisture content from the beginning of the experiment until the end of the storage period.

Table (1). The effect of different treatments on the percentage of moisture in the Gelatin-coated labneh.

\begin{tabular}{|c|c|c|c|}
\hline \multicolumn{3}{|c|}{ Storage time at a temperature $(5 \pm 2){ }^{\circ} \mathrm{C}$} & \multirow{2}{*}{ Treatments } \\
\hline 14 day & 7 day & 1 day & \\
\hline $\begin{array}{c}70.38 \\
\pm 1.02 \mathrm{~d}\end{array}$ & $\begin{array}{c}72.18 \\
\pm 0.88 \mathrm{~d}\end{array}$ & $\begin{array}{c}77.30 * \\
\pm 1.18 \mathrm{a}^{* *}\end{array}$ & $\mathrm{~T} 1$ \\
\hline $\begin{array}{r}71.25 \\
\pm 0.94 \mathrm{c}\end{array}$ & $\begin{array}{r}73.62 \\
\pm 1.31 \mathrm{c}\end{array}$ & $\begin{array}{c}78.08 \\
\pm 2.02 \mathrm{a}\end{array}$ & $\mathrm{T} 2$ \\
\hline $\begin{array}{c}72.15 \\
\pm 0.32 \mathrm{~b}\end{array}$ & $\begin{array}{c}74.21 \\
\pm 1.27 \mathrm{~b}\end{array}$ & $\begin{array}{c}78.03 \\
\pm 1.25 \mathrm{a}\end{array}$ & T3 \\
\hline $\begin{array}{c}72.18 \\
\pm 1.15 \mathrm{~b}\end{array}$ & $\begin{array}{r}74.20 \\
\pm 1.14 \mathrm{~b}\end{array}$ & $\begin{array}{r}78.11 \\
\pm 1.09 \mathrm{a}\end{array}$ & $\mathrm{T} 4$ \\
\hline $\begin{array}{c}72.17 \\
\pm 1.39 \mathrm{~b}\end{array}$ & $\begin{array}{c}74.25 \\
\pm 1.62 \mathrm{~b}\end{array}$ & $\begin{array}{c}78.05 \\
\pm 1.75 \mathrm{a}\end{array}$ & T5 \\
\hline $\begin{array}{r}72.35 \\
\pm 2.11 \mathrm{a}\end{array}$ & $\begin{array}{c}74.37 \\
\pm 2.06 \mathrm{a}\end{array}$ & $\begin{array}{r}78.10 \\
\pm 1.13 \mathrm{a}\end{array}$ & T6 \\
\hline $\begin{array}{c}72.32 \\
\pm 1.57 \mathrm{a}\end{array}$ & $\begin{array}{c}74.43 \\
\pm 1.23 \mathrm{a}\end{array}$ & $\begin{array}{r}78.15 \\
\pm 2.55 \mathrm{a}\end{array}$ & $\mathrm{T} 7$ \\
\hline
\end{tabular}

*The numbers in the table are an average of three replications.

**The different letters in one column indicate significant differences at the level of $(\mathrm{P}(0.05) . \mathrm{T} 1=$ control, $\mathrm{T} 2=$ gelatin, $\mathrm{T} 3=$ gelatin + $\mathrm{GB}$, T4 = gelatin + CHNPS, T5 $=$ gelatin $+\mathrm{TiO}_{2} \mathrm{NPS} \mathrm{T} 6=$ gelatin $+\mathrm{GB}+\mathrm{CHNPS}, \mathrm{T} 7=$ gelatin $+\mathrm{GB}+\mathrm{TiO}_{2} \mathrm{NPS}$.

The results were converged and were not affected by the type of coating or the additives (the first day). The slight differences in the moisture content could be attributed to the fact that the manual curd pressed process did not completely separate the whey from the curd. [16]. The percentage of humidity in all treatments did not exceed what was specified by the Iraqi Standard for labneh [17], which is that it should not be less than $72 \%$. The gradual decrease continued with the length of the storage period until the lowest moisture level was reached at the end of the storage period for the treatments, which amounted to 70.38, 71.25, 72.15, 72.18, 72.17, 72.35, $72.32 \%$, respectively. These results are in agreement with what was reported by Al. Otaibi and El. Demerdash [18] found that the moisture percentage in labneh decreased after 14 days of storage from 77.05 to $72.86 \%$. The gradual decrease in humidity with increasing storage periods was attributed to the seepage of whey from labneh. These results are in agreement with the assertion of Ramos et al., [19], who indicated that the moisture content of milk coated with whey protein films decreased slightly compared to the non-coated treatment. The reason can be attributed to the ability of these films to hold moisture, which is affected by the increase in crosslinking by chemical, physical and enzymatic treatments.

Fat percentage: The results in Table (2) showed after one day of storage, no significant difference was found in the fat percentage in all treatments. Otherwise, the non-coated labneh and coated with gelatin or gelatin films 
with added GB, CHNPs, and TiO2NPs showed a significant increase $(\mathrm{P}<0.05)$ in the lipid content from the experiment time until the end of the storage period at the time 14 days.

Table (2). The effect of different treatments on the percentage of fat in the labneh coated with gelatin films.

\begin{tabular}{|c|c|c|c|}
\hline \multicolumn{3}{|c|}{ Storage time at a temperature $(5 \pm 2){ }^{\circ} \mathrm{C}$} & \\
\hline 14 days & 7 days & 1 day & \\
\hline $\begin{array}{c}8.53 \\
\pm 0.02^{\mathrm{c}}\end{array}$ & $\begin{array}{c}7.96 \\
\pm 0.06^{\mathrm{c}}\end{array}$ & $\begin{array}{c}7.51^{*} \\
\pm 0.22^{\mathrm{a} * *}\end{array}$ & $\mathrm{~T} 1$ \\
\hline $\begin{array}{c}8.72 \\
\pm 0.94^{\mathrm{b}}\end{array}$ & $\begin{array}{c}8.08 \\
\pm 0.19^{\mathrm{b}} \\
\end{array}$ & $\begin{array}{c}7.59 \\
\pm 0.17^{\mathrm{a}} \\
\end{array}$ & $\mathrm{T} 2$ \\
\hline $\begin{array}{c}8.85 \\
\pm 0.32^{\mathrm{a}} \\
\end{array}$ & $\begin{array}{c}8.22 \\
\pm 0.21^{\mathrm{a}} \\
\end{array}$ & $\begin{array}{c}7.64 \\
\pm 0.08^{\mathrm{a}}\end{array}$ & T3 \\
\hline $\begin{array}{c}8.80 \\
\pm 0.36^{\mathrm{a}} \\
\end{array}$ & $\begin{array}{c}8.25 \\
\pm 0.09^{\mathrm{a}} \\
\end{array}$ & $\begin{array}{c}7.69 \\
\pm 0.03^{\mathrm{a}} \\
\end{array}$ & $\mathrm{T} 4$ \\
\hline $\begin{array}{c}8.89 \\
\pm 0.33^{\mathrm{a}}\end{array}$ & $\begin{array}{c}8.26 \\
\pm 0.41^{\mathrm{a}}\end{array}$ & $\begin{array}{c}7.61 \\
\pm 0.36^{\mathrm{a}}\end{array}$ & T5 \\
\hline $\begin{array}{c}8.91 \\
\pm 0.12^{\mathrm{a}}\end{array}$ & $\begin{array}{c}8.26 \\
\pm 0.07^{\mathrm{a}}\end{array}$ & $\begin{array}{c}7.68 \\
\pm 0.28^{\mathrm{a}}\end{array}$ & T6 \\
\hline $\begin{array}{c}8.93 \\
\pm 0.48^{\mathrm{a}}\end{array}$ & $\begin{array}{c}8.28 \\
\pm 0.13^{\mathrm{a}}\end{array}$ & $\begin{array}{c}7.64 \\
\pm 0.15^{\mathrm{a}}\end{array}$ & $\mathrm{T} 7$ \\
\hline
\end{tabular}

*The numbers in the table are an average of three replications.

**The different letters in one column indicate significant differences at the level of $(\mathrm{P}<(0.05) . \mathrm{T} 1=$ control, $\mathrm{T} 2=$ gelatin, $\mathrm{T} 3=$ gelatin + GB E, T4 = gelatin + CHNPS, T5 = gelatin $+\mathrm{TiO}_{2} \mathrm{NPS}, \mathrm{T} 6=$ gelatin $+\mathrm{GBE}+\mathrm{CHNPS}, \mathrm{T} 7=$ gelatin $\mathrm{GB}+\mathrm{TiO}_{2} \mathrm{NPS}$

The Iraqi Standard numbered 1384 (1989) stipulates that the product should be completely free of foreign fats except for milk fat. The limits of fat percentage dose not mentioned in this Standard. These results were close to AL-Hadidi results [16] it was found that Iraqi labneh contained $6.2 \%$ of fat, a gradual increase occurred with increasing the storage period until reaching the highest fat percentage at the end of the storage period for transactions T1, T2, T3, T4, T5, T6, and T7, which amounted to 8.53, 8.72, 8.85, 8.80, 8.89, 8.91, 8.93\%, respectively, when comparing the treatments, it was noticed that the lowest fat percentage was $8.53 \%$ for the uncoated control sample $\mathrm{T} 1$ while the best treatments were in its ability to maintain its lipid content as treatment T7. These results were in agreement with the findings of Al. Otaibi and El. Demerdash [18] found an increase in the percentage of fat in the yogurt after storage for 14 days. The reason for the increasing the average percentage of fat for different treatments is decreasing in the moisture content in the other treatments during the storage periods. However, Ramos et al. [19] indicated that the lipid content of dairy products coated with protein films decreased slightly compared to the non-coated treatment. The reason may be attributed to the ability of these films to retain lipid, which is affected by increased crosslinking by chemical, physical and enzymatic treatments. From table (3), the results of protein percentage indicated that all samples of coated and uncoated labneh with gelatin films or with added GB, ChNPs, and TiO2NPs showed a significant increase $(\mathrm{P}<0.05)$ in the protein content from the beginning to the end of the storage period at time 14 days. The protein ratios for $\mathrm{T} 1, \mathrm{~T} 2, \mathrm{~T} 3, \mathrm{~T} 4$, T5, T6, and T7 treatments at one day were 9.76, 9.79, 9.81, 9.80, 9.81, 9.83, and 9.82\%, respectively. The percentage of protein in all treatments did not exceed what was specified by the Syrian Standard for labneh No. 178 of (1984), which is not less than 8\%. It was also noted from the Table that the protein ratios increased gradually with the progression of the storage period, as the highest levels of protein for the same treatments were reached in Above 10.31, 10.37, 10.45, 10.44, 10.44, 10.47, 10.48\%, respectively at the time of 14 days. The percentage of protein in the labneh increases slightly in the different treatments and during the storage periods. The increase in the rate of protein in the different treatments during the storage periods is due to the decrease in the percentage of moisture in the labneh. These results came compatible with Al. Atibi et. al [18] and Al-Kaabi [21]. They stated that the continuous decrease in the moisture content of the labneh during the storage stages affects the balance between other components, including fat, protein, and ash. The results were similar to Zheng et al. [22], who found a difference in the protein ratio between the treatments that accounted for the difference in the moisture content values and the chemical composition of the anti-microorganisms added to the coating and the presence of proteolytic bacteria. 
Table (3). the effect of different treatments on the percentage of protein in the labneh coated with gelatin.

\begin{tabular}{|c|c|c|c|}
\hline \multicolumn{3}{|c|}{ Storage time at a temperature $(5 \pm 2){ }^{\circ} \mathrm{C}$} & \multirow{2}{*}{ Treatments } \\
\hline 14 days & 7 days & 1 day & \\
\hline $\begin{array}{c}2.20 \\
\pm 0.07^{\mathrm{c}}\end{array}$ & $\begin{array}{c}2.11 \\
\pm 0.08^{\mathrm{c}}\end{array}$ & $\begin{array}{c}1.21^{*} \\
\pm 0.01^{\mathrm{a}} * *\end{array}$ & $\mathrm{~T} 1$ \\
\hline $\begin{array}{c}2.35 \\
\pm 0.05^{\mathrm{b}}\end{array}$ & $\begin{array}{c}2.20 \\
\pm 0.04^{\mathrm{b}} \\
\end{array}$ & $\begin{array}{c}1.24 \\
\pm 0.05^{\mathrm{a}} \\
\end{array}$ & $\mathrm{T} 2$ \\
\hline $\begin{array}{c}2.41 \\
\pm 0.10^{\mathrm{a}}\end{array}$ & $\begin{array}{c}2.27 \\
\pm 0.01^{\mathrm{a}}\end{array}$ & $\begin{array}{c}1.23 \\
\pm 0.05^{\mathrm{a}}\end{array}$ & $\mathrm{T} 3$ \\
\hline $\begin{array}{c}2.42 \\
\pm 0.03^{\mathrm{a}}\end{array}$ & $\begin{array}{c}2.30 \\
\pm 0.09^{\mathrm{a}}\end{array}$ & $\begin{array}{c}1.25 \\
\pm 0.03^{\mathrm{a}}\end{array}$ & $\mathrm{T} 4$ \\
\hline $\begin{array}{c}2.40 \\
\pm 0.05^{\mathrm{a}}\end{array}$ & $\begin{array}{c}2.27 \\
\pm 0.03^{\mathrm{a}}\end{array}$ & $\begin{array}{c}1.25 \\
\pm 0.09^{\mathrm{a}}\end{array}$ & T5 \\
\hline $\begin{array}{c}2.41 \\
\pm 0.01^{\mathrm{a}}\end{array}$ & $\begin{array}{c}2.31 \\
\pm 0.05^{\mathrm{a}}\end{array}$ & $\begin{array}{c}1.26 \\
\pm 0.03^{\mathrm{a}}\end{array}$ & T6 \\
\hline $\begin{array}{c}2.42 \\
\pm 0.04^{\mathrm{a}} \\
\end{array}$ & $\begin{array}{c}2.31 \\
\pm 0.09^{\mathrm{a}} \\
\end{array}$ & $\begin{array}{c}1.26 \\
\pm 0.01^{\mathrm{a}} \\
\end{array}$ & $\mathrm{T} 7$ \\
\hline
\end{tabular}

*The numbers in the table are an average of three replications.

$* *$ The different letters in one column indicate significant differences at the level of $(\mathrm{P}(0.05) . \mathrm{T} 1=$ control, $\mathrm{T} 2=$ gelatin, $\mathrm{T} 3=$ gelatin + GB extract, $\mathrm{T} 4=$ gelatin + CHNPS, T5 $=$ gelatin $+\mathrm{TiO}_{2} \mathrm{NPS}, \mathrm{T} 6=$ gelatin $+\mathrm{GB}+\mathrm{CHNPS}, \mathrm{T} 7=$ gelatin $+\mathrm{GB}+\mathrm{TiO}_{2} \mathrm{NPS}$.

Regarding the percentage of ash in Table (4), the results that all samples of uncoated labneh and coated with gelatin films or gelatin with added GB, ChNPs, and TiO2NPs showed a significant increase $(\mathrm{P}<0.05)$ in the percentage of ash from the beginning of experiment time until the end of the storage period at the time 14 days. The protein ratios for T1, T2, T3, T4, T5, T6, and T7 treatments at one day were 1.21, 1.24, 1.23, 1.25, 1.26, and $1.26 \%$, respectively. These results are close to El-Samragy et al. [22], who have indicated the difference in the proportion of ash with different treatments. Moreover, these differences may relate to many factors such: as the difference in the samples taken, the chemicals used in the assessment, or any other factors that may affect the accuracy of the estimation as it is constant and does not change in the samples, the follow-up of the results in the Table shows a gradual increase in the proportion of ash with an increase in the storage period in the parameters T1, T2, T3, T4, T5, T6, T7, which amounted to 2.20, 2.35, 2.41, 2.42, 2.40, 2.41, and 2.42\%, respectively.

These results were identical to Al. Otaibi and El. Demerdash [18] who have reported the increase in the proportion of ash in the labneh with the advance of the storage period of the cheese. The results agree with Ahmad [7], who indicated that the percentage of ash in cheese samples coated with gelatinous films and supported with nanoparticles gradually increased as the storage period lengthened. In proportions of moisture content. According to the carbohydrate percentage shown in Table (5), The results indicated that the percentages estimated one day in all the treatments under study ranged from 3.12\% for treatment T6 to $4.22 \%$ For transaction $\mathrm{T} 1$. The carbohydrate ratios for all treatments increased gradually with the lengthening of the storage period. They reached the highest rate at $8.58 \%$ for treatment $\mathrm{T} 1$ at the time of 14 days, and while the treatment T4 gave the lowest rate of 5.85\%. The above results are consistent with Hassabo [1] when he proved the same for carbohydrates

The gradual rise in carbohydrate ratios for all treatments with prolonged storage periods may attribute to the decrease in moisture content ratios or the difference in the percentage of moisture loss. The effect of the rest of the cheese components on the same carbohydrate percentage was calculating. 
Table (4). The effect of different treatments on the percentage of ash in the labneh coated with gelatin.

\begin{tabular}{|c|c|c|c|}
\hline \multicolumn{3}{|c|}{ Storage time at a temperature $(5 \pm 2){ }^{\circ} \mathrm{C}$} & \multirow{2}{*}{ Treatments } \\
\hline 14 days & 7 days & 1 day & \\
\hline $\begin{array}{c}2.20 \\
\pm 0.07^{\mathrm{c}}\end{array}$ & $\begin{array}{c}2.11 \\
\pm 0.08^{c}\end{array}$ & $\begin{array}{c}1.21^{*} \\
\pm 0.01^{\mathrm{a} * *}\end{array}$ & $\mathrm{~T} 1$ \\
\hline $\begin{array}{c}2.35 \\
\pm 0.05^{\mathrm{b}}\end{array}$ & $\begin{array}{c}2.20 \\
\pm 0.04^{\mathrm{b}}\end{array}$ & $\begin{array}{c}1.24 \\
\pm 0.05^{\mathrm{a}}\end{array}$ & $\mathrm{T} 2$ \\
\hline $\begin{array}{c}2.41 \\
\pm 0.10^{\mathrm{a}}\end{array}$ & $\begin{array}{c}2.27 \\
\pm 0.01^{\mathrm{a}}\end{array}$ & $\begin{array}{c}1.23 \\
\pm 0.05^{\mathrm{a}}\end{array}$ & $\mathrm{T} 3$ \\
\hline $\begin{array}{c}2.42 \\
\pm 0.03^{\mathrm{a}}\end{array}$ & $\begin{array}{c}2.30 \\
\pm 0.09^{\mathrm{a}}\end{array}$ & $\begin{array}{c}1.25 \\
\pm 0.03^{\mathrm{a}}\end{array}$ & $\mathrm{T} 4$ \\
\hline $\begin{array}{c}2.40 \\
\pm 0.05^{\mathrm{a}}\end{array}$ & $\begin{array}{c}2.27 \\
\pm 0.03^{\mathrm{a}}\end{array}$ & $\begin{array}{c}1.25 \\
\pm 0.09^{\mathrm{a}}\end{array}$ & T5 \\
\hline $\begin{array}{c}2.41 \\
\pm 0.01^{\mathrm{a}}\end{array}$ & $\begin{array}{c}2.31 \\
\pm 0.05^{\mathrm{a}}\end{array}$ & $\begin{array}{c}1.26 \\
\pm 0.03^{\mathrm{a}}\end{array}$ & T6 \\
\hline $\begin{array}{c}2.42 \\
\pm 0.04^{\mathrm{a}}\end{array}$ & $\begin{array}{c}2.31 \\
\pm 0.09^{\mathrm{a}}\end{array}$ & $\begin{array}{c}1.26 \\
\pm 0.01^{\mathrm{a}}\end{array}$ & $\mathrm{T} 7$ \\
\hline
\end{tabular}

*The numbers in the table are an average of three replications.

**The different letters in one column indicate significant differences at the level of $(\mathrm{P}<(0.05)$. $\mathrm{T} 1=$ control, $\mathrm{T} 2=$ gelatin, $\mathrm{T} 3=$ gelatin + GB extract, $\mathrm{T} 4=$ gelatin + CHNPS, T5 $=$ gelatin $+\mathrm{TiO}_{2} \mathrm{NPS}, \mathrm{T} 6=$ gelatin $+\mathrm{GB}+\mathrm{CHNPS}, \mathrm{T} 7=$ gelatin $+\mathrm{GB}+\mathrm{TiO}_{2} \mathrm{NPS}$.

Table (5). Effect of different treatments on the percentage of carbohydrates in labneh coated with gelatin films.

\begin{tabular}{|c|c|c|c|}
\hline \multicolumn{3}{|c|}{ Storage time at a temperature $(5 \pm 2){ }^{\circ} \mathrm{C}$} & \multirow{2}{*}{ Treatments } \\
\hline 14 days & 7 days & 1 day & \\
\hline $\begin{array}{c}8.58 \\
\pm 0.76^{\mathrm{a}}\end{array}$ & $\begin{array}{c}7.70 \\
\pm 0.29^{\mathrm{a}}\end{array}$ & $\begin{array}{c}4.22^{*} \\
\pm 0.34^{\mathrm{a} * *}\end{array}$ & $\mathrm{~T} 1$ \\
\hline $\begin{array}{c}7.31 \\
\pm 0.53^{\mathrm{b}}\end{array}$ & $\begin{array}{c}5.99 \\
\pm 0.78^{\mathrm{b}}\end{array}$ & $\begin{array}{c}3.30 \\
\pm 0.61^{\mathrm{b}}\end{array}$ & $\mathrm{T} 2$ \\
\hline $\begin{array}{c}6.14 \\
\pm 0.22^{c}\end{array}$ & $\begin{array}{c}5.13 \\
\pm 0.49^{c}\end{array}$ & $\begin{array}{c}3.29 \\
\pm 0.52^{\mathrm{b}}\end{array}$ & $\mathrm{T} 3$ \\
\hline $\begin{array}{c}6.16 \\
\pm 0.41^{\mathrm{c}}\end{array}$ & $\begin{array}{c}5.10 \\
\pm 0.36^{\mathrm{c}}\end{array}$ & $\begin{array}{c}3.15 \\
\pm 0.16^{\mathrm{b}}\end{array}$ & $\mathrm{T} 4$ \\
\hline $\begin{array}{c}6.10 \\
\pm 0.37^{c}\end{array}$ & $\begin{array}{c}5.03 \\
\pm 0.32^{c}\end{array}$ & $\begin{array}{c}3.28 \\
\pm 0.58^{\mathrm{b}}\end{array}$ & $\mathrm{T} 5$ \\
\hline $\begin{array}{c}5.86 \\
\pm 0.12^{\mathrm{d}}\end{array}$ & $\begin{array}{c}4.95 \\
\pm 0.18^{\mathrm{c}}\end{array}$ & $\begin{array}{c}3.13 \\
\pm 0.41^{\mathrm{b}}\end{array}$ & T6 \\
\hline $\begin{array}{c}5.85 \\
\pm 0.62^{d}\end{array}$ & $\begin{array}{c}4.77 \\
\pm 0.05^{\mathrm{d}}\end{array}$ & $\begin{array}{c}3.12 \\
\pm 0.19^{\mathrm{b}}\end{array}$ & $\mathrm{T} 7$ \\
\hline
\end{tabular}

*The numbers in the table are an average of three replications.

**The different letters in one column indicate significant differences at the level of $(\mathrm{P}<(0.05)$. T1 $=$ control, $\mathrm{T} 2=$ gelatin, $\mathrm{T} 3=$ gelatin + GBE, T4 = gelatin + CHNPS, T5 = gelatin $+\mathrm{TiO}_{2} \mathrm{NPS} \mathrm{T} 6=$ gelatin $+\mathrm{GB}+\mathrm{CHNPS}, \mathrm{T} 7=$ gelatin $+\mathrm{GB}+\mathrm{TiO}_{2} \mathrm{NPS}$

$\mathrm{pH}$ values: The results of estimating the $\mathrm{pH}$ showed a slight decrease in its value during the storage stages of the labneh, and for all treatments, Table (6) showed that the $\mathrm{pH}$ values at the beginning of the storage period for the treatments T1, T2, T3, T4, T5, T6, T7) (the time is one day) 4.47, 4.49, 4.48, 4.50, 4.51, 4.51, 4.50, respectively. They were close to each other and did not show significant differences. These results were consistent with what Harfoush [24] found for labneh made from pasteurized milk, where they found that the $\mathrm{pH}$ values ranged. Between 3.95 - 4.54 The $\mathrm{pH}$ values gradually decreased with the continuation of storage until they reached the lowest values at the end of the storage period (14 days) for the treatments, reaching 4.16, 4.23, 4.32, 4.34, 4.33, 4.35, and 4.36, respectively.The results are consistent with what Hassabo [1] found, which proved that the $\mathrm{pH}$ 
value decreased gradually as the storage period was prolonged from 4.63 to 4.13 . The high level of lactic acid belongs to the action of the initiator bacteria. It is noticeable that the $\mathrm{pH}$ values of all the gelatin-coated treatments with the addition of GBE, ChNPs, and TiO2NPs and the gelatin-coated, were within close rates and higher than the $\mathrm{pH}$ value of the uncoated $\mathrm{T} 1$ treatment. The reason for the low $\mathrm{pH}$ values of the treatments may attributes to the fermentation of lactose sugar in the labneh samples affected by the microbial content and the moisture levels that affect the activity of microorganisms [25].

Table (6). The effect of different treatments on the $\mathrm{pH}$ values in the stored labneh with gelatinous films.

\begin{tabular}{|c|c|c|c|}
\hline \multicolumn{3}{|c|}{ Storage time at a temperature $(5 \pm 2)^{\circ} \mathrm{C}$} & \multirow{2}{*}{ Treatments } \\
\hline 14 days & 7 days & 1 day & \\
\hline $\begin{array}{c}4.16 \\
\pm 0.56^{\mathrm{c}}\end{array}$ & $\begin{array}{c}4.33 \\
\pm 0.12^{\mathrm{c}}\end{array}$ & $\begin{array}{c}4.47^{*} \\
\pm 0.52^{\mathrm{a} * *}\end{array}$ & $\mathrm{~T} 1$ \\
\hline $\begin{array}{c}4.23 \\
\pm 0.13^{\mathrm{b}}\end{array}$ & 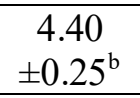 & $\begin{array}{c}4.49 \\
\pm 0.46^{\mathrm{a}}\end{array}$ & $\mathrm{T} 2$ \\
\hline $\begin{array}{c}4.32 \\
\pm 0.39^{\mathrm{a}}\end{array}$ & $\begin{array}{c}4.44 \\
\pm 0.09^{\mathrm{a}}\end{array}$ & $\begin{array}{c}4.48 \\
\pm 0.18^{\mathrm{a}}\end{array}$ & $\mathrm{T} 3$ \\
\hline $\begin{array}{c}4.34 \\
\pm 0.28^{\mathrm{a}}\end{array}$ & $\begin{array}{c}4.45 \\
\pm 0.38^{\mathrm{a}}\end{array}$ & $\begin{array}{c}4.50 \\
\pm 0.71^{\mathrm{a}}\end{array}$ & $\mathrm{T} 4$ \\
\hline $\begin{array}{c}4.33 \\
\pm 0.11^{\mathrm{a}}\end{array}$ & $\begin{array}{c}4.46 \\
\pm 0.71^{\mathrm{a}}\end{array}$ & $\begin{array}{c}4.51 \\
\pm 0.44^{\mathrm{a}}\end{array}$ & T5 \\
\hline $\begin{array}{c}4.35 \\
\pm 0.05^{\mathrm{a}}\end{array}$ & $\begin{array}{c}4.47 \\
\pm 0.14^{\mathrm{a}}\end{array}$ & $\begin{array}{c}4.51 \\
\pm 0.82^{\mathrm{a}}\end{array}$ & T6 \\
\hline $\begin{array}{c}4.36 \\
\pm 0.47^{\mathrm{a}}\end{array}$ & $\begin{array}{c}4.48 \\
\pm 0.38^{\mathrm{a}}\end{array}$ & $\begin{array}{c}4.50 \\
\pm 0.16^{\mathrm{a}}\end{array}$ & $\mathrm{T} 7$ \\
\hline
\end{tabular}

*The numbers in the table are an average of three replications.

**The different letters in one column indicate significant differences at the level of $(\mathrm{P}<(0.05) . \mathrm{T} 1=$ control, $\mathrm{T} 2=$ gelatin, $\mathrm{T} 3=$ gelatin + GBE, T4 = gelatin + CHNPS, T5 = gelatin $+\mathrm{TiO}_{2} \mathrm{NPS}$, T6 = gelatin $+\mathrm{GB}+\mathrm{CHNPS}, \mathrm{T} 7=$ gelatin $+\mathrm{GB}+\mathrm{TiO}_{2} \mathrm{NPS}$

Table (7). The effect of different treatments on the percentage of free fatty acids in labneh coated with gelatin films stored for 14 days.

\begin{tabular}{|c|c|c|c|}
\hline \multicolumn{3}{|c|}{ Storage time at a temperature $(5 \pm 2){ }^{\circ} \mathrm{C}$} & \multirow{2}{*}{ Treatments } \\
\hline 14 days & 7 days & 1 day & \\
\hline $\begin{array}{c}0.39 \\
\pm 0.15^{\mathrm{c}}\end{array}$ & $\begin{array}{c}0.31 \\
\pm 0.01^{\mathrm{c}}\end{array}$ & $\begin{array}{c}0.09^{*} \\
\pm 0.00^{\mathrm{b} * *}\end{array}$ & $\mathrm{~T} 1$ \\
\hline $\begin{array}{c}0.35 \\
\pm 0.12^{\mathrm{b}}\end{array}$ & $\begin{array}{c}0.26 \\
\pm 0.25^{\mathrm{b}}\end{array}$ & $\begin{array}{c}0.05 \\
\pm 0.00^{\mathrm{a}} \\
\end{array}$ & $\mathrm{T} 2$ \\
\hline $\begin{array}{c}0.32 \\
\pm 0.11^{\mathrm{a}} \\
\end{array}$ & $\begin{array}{c}0.21 \\
\pm 0.09^{\mathrm{a}}\end{array}$ & $\begin{array}{c}0.06 \\
\pm 0.01^{\mathrm{a}}\end{array}$ & $\mathrm{T} 3$ \\
\hline $\begin{array}{c}0.32 \\
\pm 0.06^{\mathrm{a}}\end{array}$ & $\begin{array}{c}0.20 \\
\pm 0.03^{\mathrm{a}}\end{array}$ & $\begin{array}{c}0.05 \\
\pm 0.00^{\mathrm{a}}\end{array}$ & T4 \\
\hline $\begin{array}{c}0.31 \\
\pm 0.12^{\mathrm{a}}\end{array}$ & $\begin{array}{c}0.19 \\
\pm 0.07^{\mathrm{a}} \\
\end{array}$ & $\begin{array}{c}0.05 \\
\pm 0.00^{\mathrm{a}}\end{array}$ & T5 \\
\hline $\begin{array}{c}0.31 \\
\pm 0.08^{\mathrm{a}}\end{array}$ & $\begin{array}{c}0.20 \\
\pm 0.01^{\mathrm{a}}\end{array}$ & $\begin{array}{c}0.04 \\
\pm 0.00^{\mathrm{a}}\end{array}$ & T6 \\
\hline $\begin{array}{c}0.29 \\
\pm 0.11^{\mathrm{a}}\end{array}$ & $\begin{array}{c}0.17 \\
\pm 0.08^{\mathrm{a}}\end{array}$ & $\begin{array}{c}0.05 \\
\pm 0.00^{\mathrm{a}}\end{array}$ & $\mathrm{T} 7$ \\
\hline
\end{tabular}

*The numbers in the table are an average of three replications.

**The different letters in one column indicate significant differences at the level of $(\mathrm{P} \leq 0.05) . \mathrm{T} 1=$ control, $\mathrm{T} 2=$ gelatin, $\mathrm{T} 3=$ gelatin + GBE, T4 = gelatin + CHNPS, T5 = gelatin $+\mathrm{TiO}_{2} \mathrm{NPS}, \mathrm{T} 6=$ gelatin $+\mathrm{GBE}+\mathrm{CHNPS}, \mathrm{T} 7=$ gelatin $+\mathrm{GBE}+\mathrm{TiO}_{2} \mathrm{NPS}$. 
Concerning the percentage of free fatty acids in Table [7], all samples of non-encapsulated labneh and coated with gelatin or gelatin with added GB, ChNPs and TiO2NPs showed a significant increase $(\mathrm{P}<0.05)$ in the percentage of free fatty acids from the beginning of the time of the experiment until the end of the storage period at the time 14 days.The ratios for the parameters T1, T2, T3, T4, T5, T6, and T7 at the time of one day were $0.09,0.05,0.06,0.05,0.05,0.04,0.05 \%$, respectively. When the storage period reached 14 days, the significant difference in the value of free fatty acids for the parameters T4, T5, T6, and T7, which amounted to $0.32,0.31$, $0.31,0.29 \%$, respectively, compared with the treatments $\mathrm{T} 1$ and $\mathrm{T} 2$, which were at $0.39,0.35 \%$ respectively. The results are consistent with what Soleimani et al. [26] found with lower free fatty acid levels in the milk product samples coated with xanthan gum than the non-encapsulated control sample. This may be because of the role of GBE and nanoparticles inhibiting microorganisms by blocking the action of Gram-negative bacteria contaminating labneh and reducing the decomposition of its component. This includes the aforementioned fatty acids, compared with the two treatments $\mathrm{T} 2$ and T1, with higher microbial content, which lead to lower quality of samples.

\section{Conclusions}

Chemical tests of labneh demonstrated a decrease in moisture percentages for all treatments, an increase in the percentages of protein, fat, carbohydrates, and ash, and a slight decrease in $\mathrm{pH}$ values and free fatty acids with an increasing storage period. The best treatments were in its ability to maintain its lipid content as treatment T7 (gelatin + GBE + Tio2NPS). T4(gelatin + CHNPS) gave the lowest rate of carbohydrate ratios.

\section{References}

[1] Hassabo, R. M, " Chemical Composition and Quality of Labneh Contaning Palm Oil Made by Frequent Homogenizer, " Journal of Food and Dairy Scines, vol.8,no.11,Nov., pp. 431- 434, 2017.

[2] Kulczyński, B. and Gramza-Michałowska, A., " Goji Berry (Lycium barbarum): Composition and Health Effects A Review, " Pol. J. Food Nutr. Sci.,vol. 66,no. 2,pp. 67-75, 2016.

[3] Abdeltwab, W., Abdelaliem, Y., Metry, W. and Eldeghedy, M., " Antimicrobial effect of Chitosan and Nanochitosan against some pathogen and spolige Microorganisms,"J.Adv.Lab.Res.Biol.,vol. 10,no. 1,pp.8-15. 2019.

[4] Schilling, K., Bradford, B., Castelli, D. and Dufour, E., " Human safety review of nano titanium dioxide and zinc oxide,"Journal photochem photobiological scines, vol. 9,no.4, pp.495-509, 2010.

[5] Chan, E. W. C.; Lim, Y. Y., and Chew, Y. L., " Antioxidant activity of Camellia sinensis leaves and tea from a lowland plantation in Malaysia,"Journal Food chemistry,vol. 102,no. 4,pp. 1214-1222, 2007.

[6] De Carvalho, R. A. and Grosso, C. R., " Characterization of gelatin based films modified with transglutaminase glyoxal and formaldehyde," Food hydrocolloids,vol. 18,no.5,pp. 717-726, 2004.

[7] Nahar,K.A., " Chemical and biological evaluation of some synthesized nanoparticles loaded on gelatin for use as a membrane in the preservation of soft cheese," PhD. thesis, Tikrit University, College of Agriculture. 2020.

[8] Al-Kadamany, E., Khattar, M. Haddad, Th. and Toufili, I., " Determination of Shelf life of concentrated yoghurt produced by in-Bag straining of set yogurt using hazard analysis," Journal of Dairy Science, vol.85, pp.1023-1030, 2002.

[9] Ling, E.R. ", A textbook of dairy chemistry, " practical, Chapman and Hall. LTD, vol.II (London). 2008.

[10] Min, D. B. and Ellefson, W. C., " Fat analysis " in: food analysis, Nielsen, S. S. Fourth Edition. Springer Science and Business Media. (Chapter 8). pp. 118-132, 2010.

[11] Hool, R. Barbano, D. M. Bradley, R. Bulthaus, M. Lynch, J. and Reddy, R., " Chemical and physical Methods, " In: Standard Methods for the Examination of Dairy products Wehr, H.M. and Frank, J.F. (Ed). 17th ed. Washington, American Public Health Association. (Chapter 15), pp. 363-532,2004.

[12] AOAC. Official Methods of Analysis of AOAC International. 18th edition., revision 3. Gaithersburg, Maryland, AOAC International. Ch. 17. USA., 2010.

[13] Ihekoronye, A., " Integrated Food Science and Technology for the tropics," Mc Millan press Ltd London. 1985.

[14] SAS, Statistical Analysis System, User's Guide. Statistical. Version 9.1th ed. SAS. Inst. Inc. Cary. N.C. USA., 2012.

[15] Duncan, D.B., " Multiple range and multiple "F" test.," Biometric, vol. 11, pp.1-42, 1955. 
[16] Al-Hadidi, L. T., " Manufacture of therapeutic labneh by various methods using Lactobacillus acidophilus and Lactobacillus casei, " M. S. thesis, University of Baghdad, College of Agriculture, 2009.

[17] Central Organization for Standardization and Quality Control, Dairy products. Dry milk (labneh). QC No. 1384, 1989.

[18] Al.Otaibi, M. and El.Demerdash, H., " Improvement of the quality and shelf life of concentrated yoghurt (labneh) by the addition of some essential oils, " Afr. J. Microbiol. Res. Vol. 2, pp. 156-161, 2008.

[19] Ramos, Ó. L., Reinas, I., Silva, S. I., Fernandes, J. C., Cerqueira, M. A., Pereira, R. N., Vicente, A. A., Poças, M. F., Pintado, M. E. and Malcata, F. X., " Effect of whey protein purity and glycerol content upon physical properties of edible films manufactured therefrom, " Food Hydrocolloids, vol,30, pp. 110-122, 2013.

[20] Syrian Standards Organization, Dairy products. Labneh (filtered milk). QC No. 178, 1984.

[21] Al-Kaabi, A. K.," Determine of Optimum Conditions for The Production of Linoleic Acid Associated with Using Ssome Locally Isolates of Lactobacillus spp. and Use It in Dairy Products," PhD. Thesis, College of Agriculture, University of Basra, Iraq, 2015.

[22] Zhang, X. F.; Liu, Z. G.; Shen, W. and Gurunathan, S.," Silver nanoparticles: synthesis, characterization, properties, applications, and therapeutic approaches," International journal of molecular sciences, vol.17,no.9, pp. 1534, 2016.

[23] EL-samaragy, Y., " ALabneh or yoghurt cheese: a review.," Egyptian. J. Dairy Sci.,vol 25, pp.165-170. 1997.

[24] Harfoush, Mohsen., " Study of some chemical and microbial characteristics of labneh manufactured in the coastal area," Tishreen University Journal for Research and Scientific Studies., vol. 33,no. 3,pp. 53-70 , 2011.

[25] Fathollahi, I.; Hesari,J.; Azadmard,S. and Oustan, S., "Influence of Proteolysis and Soluble Calcium Levels on Textural Changes in the Interior and Exterior of Iranian UF White Cheese during Ripening, "World Acad. Sci. Eng. Technol.vol. 66, pp.844-849, 2010.

[26] Soleimani-Rambod, A., Zomorodi, S., Naghizadeh Raeisi, S., Khosrowshahi Asl, A. and Shahidi, S. A. " The effect of xanthan gum and flaxseed mucilage as edible coatings in cheddar cheese during ripening," Coatings, vol.8no.2,pp. 80, 2018. 